\title{
ANGIOTENSIN I-CONVERTING ENZYME INHIBITORY ACTIVITY, TOTAL PHENOLIC AND FLAVONOID CONTENT OF EXTRACT AND FRACTION OF JAM FRUIT LEAVES (MUNTINGIA CALABURA L.)
}

\author{
EKA LASBOI, RISSYELLY, KATRIN BASAH* \\ Department of , Faculty of Pharmacy, Universitas Indonesia, Depok, Indonesia. Email: basahkatrin@yahoo.com \\ Received: 20 April 2017, Revised and Accepted: 13 July 2017
}

ABSTRACT

Objective: Hypertension is one of the most common chronic diseases. Inhibitory activity of angiotensin I-converting enzyme (ACE) is effective on giving hypotensive effect. Jamfruit leaf (Muntingia calabura L.) was reported to have an excellent hypotensive effect. This research was aimed to test in the manner of in vitro the inhibitory activity of ACE.

Methods: This research used ACE kit-WST, total phenolic content, and total flavonoid from jam fruit leaf ethanol extract, hexane, ethyl acetate, and butanol fraction.

Results: The result showed that Jamfruit leaf extract had ACE inhibitory activity and the most active fraction was ethyl acetate fraction. Inhibitory concentration $50 \%$ value of the most active fraction, ethyl acetate fraction was $0.63 \mu \mathrm{g} / \mathrm{mL}$. Ethyl acetate fraction also provides most flavonoid and phenolic content with a value of $10.91 \mathrm{mg} / \mathrm{g}$ extract quercetin equivalent and $74.90 \mathrm{mg} / \mathrm{g}$ extract gallic acid equivalent.

Conclusions: Ethyl acetate fraction of jam fruit leaf had most flavonoid, phenolic compound, and ACE inhibitory activity.

Keywords: Muntingia calabura, Angiotensin I-converting enzyme inhibition, Antihypertensive, Phenolic, Flavonoid.

(C) 2017 The Authors. Published by Innovare Academic Sciences PvtLtd. This is an open access article under the CC BY license (http://creativecommons. org/licenses/by/4. 0/) DOI: http://dx.doi.org/10.22159/ajpcr.2017.v10s5.23123

\section{INTRODUCTION}

High blood pressure or hypertension is the most important risk factor of death and disability in the world in 2010 [1]. The prevalence of hypertension in Indonesia according to data from the Health Ministry in 2013 reached $25.8 \%$ with the highest prevalence in the Bangka Belitung by $30.9 \%$ [2]. Thus, there is a challenge in continuing to seek alternative treatment of hypertension which effective and inexpensive.

Indonesia has a variety of plants that grow well and have been used as medicine for generations. One of the most available and has many benefits the jam fruit (Muntingia calabura L.). $M$. calabura has been used as traditional medicine for hypertension from time to time. Research in Taiwan found their strong hypotensive effect through activation of nitric oxide signaling pathway of cherry or jam fruit leaf extract [3]. There was no more research on the hypotensive activity by jam fruit leaf extract. More research was necessary included the search for another hypotensive activity pathway. ACE inhibitors are the first-line medicine in the treatment of hypertension because of their effectiveness in decreasing blood pressure. ACE plays a role in the activation of angiotensin I to angiotensin II, which acts as a potent vasoconstrictor and also stop the vasodilatory effects of bradykinin [4]. Clinical analysis and meta-analysis showed a reduction in the morbidity of cardiovascular and death on the use of ACE inhibitors and suggest the use of ACE inhibitors as a treatment of the first choice while ARB working specifically inhibit the receptor that binds to angiotensin II, given to patients who are sensitive to ACE inhibitors [5]. It is also important to classify the active chemical constituents in jam fruit leaf. The search was done through this experiment by comparing the flavonoid, phenolic content, and ACE inhibitory activity of jam fruit fractions.

\section{METHODS}

This study was conducted in Phytochemical Laboratory and Quantitative Analysis of Pharmaceutical Chemistry of the Universitas
Indonesia, Depok. Work procedures done were material preparations, extractions, fractionations, ACE inhibition percentage measurements, and inhibitory concentration $50 \%\left(\mathrm{IC}_{50}\right)$ test from the extract and also total phenolic and flavonoid content measurements on jam fruit (M. calabura L.) fractions.

\section{Material preparation}

Plant determination was conducted to confirm that we used the right plant, such as jam fruit (M. calabura L.). Plant identification result showed that sample was in Muntingiaceae Family, M. calabura L. species.

\section{Extraction}

Dry and clean powdered plant was grinded to obtain a smaller size. Extraction was done by maceration. $500 \mathrm{~g}$ of powdered leaves were put into maceration container. Ethanol was added to the container (until 3-5 cm above the surface). Extraction was done $2 \times 24$ hrs; extracts were collected and evaporated using a vacuum rotary evaporator at a temperature of $55^{\circ} \mathrm{C}$ with a speed of $50 \mathrm{rpm}$.

\section{Fractionation}

Fractionation was done by solvent-solvent fractionation to separate the group of compounds according to their polarity using solvents which do not mix. Fractionation was done to $50.11 \mathrm{~g}$ of extract using n-hexane (nonpolar), ethyl acetate (semi polar), and butanol (polar) as solvents. Extracts were put into 600:600 mL polar solvent and water. Fractionations were done to obtain filtrate which is nearly colorless.

\section{ACE Inhibition assay}

ACE inhibition assay was performed using ACE kit-WST from Dojindo. Borate buffer $\mathrm{pH} 8.3$ containing $380 \mathrm{mM} \mathrm{NaCl}$ was used as a buffer. Absorbance measurements carried out at a wavelength of $450 \mathrm{~nm}$ uses filter-based microplate reader. Samples were diluted into 6 concentrations which was $100,25,12.5,6.25,3.125$, and $1.563 \mu \mathrm{g} / \mathrm{mL}$. Captopril was used as a control standard. 
Total phenolic content (TPC)

Determination of TPC of the sample was done using the Folin-Ciocalteu assay and followed the methods of work of Al-Saeedi and Hossain (2015) with some modifications [6]. TPC expressed as the total gallic acid equivalent (GAE). $200 \mathrm{~mL}$ and put in a tube, $200 \mathrm{~mL}$ of sample was put into the reaction tube. $1.5 \mathrm{~mL}$ of Folin-Ciocalteu reagent was added to the tube. Then, the tube was incubated in the dark at room temperature for 5 minutes. After 5 minutes, $1.5 \mathrm{~mL}$ of $\mathrm{Na}_{2} \mathrm{CO}_{3} 6 \%$ was added to the tube and incubated back during the time of incubation in the dark and at room temperature. After incubation measured the solution using a UV-Vis spectrophotometer at a wavelength of optimum.

\section{Total flavonoid (TF)}

TF content was determined by the method of Chang et al. [7]. A total of $0.5 \mathrm{~mL}$ sample was added to $1.5 \mathrm{~mL}$ of methanol then followed by the addition of $0.1 \mathrm{~mL}$ of $\mathrm{AlCl}_{3}, 10 \% 0.1 \mathrm{~mL}$ of $1 \mathrm{M}$ sodium acetate, and $2.8 \mathrm{~mL}$ of aquadest. After incubation in maximum incubation time, the absorbance was measured at the maximum wavelength. Level of TF was expressed in mg quercetin equivalent $(\mathrm{QE}) / \mathrm{g}$ extract.

\section{RESULTS AND DISCUSSIONS}

\section{ACE inhibitor activity assay}

ACE kit-WST was selected for testing fast, accurate, and specific. The test was done using a microplate reader, so it was time saving and requires only small amounts reagents. Most of the conventional methods based on the principle of formation of hippuryl-histidyl- leucine (HHL) by the action of ACE. The product or hippuric acid will be read with a spectrophotometer at a wavelength of $228 \mathrm{~nm}$. ACE activity readings could be disturbed by HHL which were not hydrolyzed which also resulted in strong absorption at a wavelength of $228 \mathrm{~nm}$ [8]. ACE is an enzyme that works in a non-specific cut two amino acids from amino acid sequence of the substrate. ACE kit-WST used 3-hidroksibutirilglisil-glisil-glycine (3HB-GGG) as a substrate solution. Previously many researches have been done using substrates glycineglycine and give good results [9]. Assay using ACE Kit-WST followed the principle of the assay by Lam et al. [10]. In principle, as the ACE enzyme dipeptidilkarboksi peptidase works by cutting two peptides from peptide chains on its C terminal. ACE inhibitory activity test is performed by measuring the amount of $3 \mathrm{HB}$ obtained from cutting two peptide substrates 3HB-GGG by ACE activity by measuring uptake of WST-1 formazan. Enzymatic reactions occur at a temperature of $37^{\circ} \mathrm{C}$. Absorbance measurements carried out at a wavelength of $450 \mathrm{~nm}$ uses filter-based microplate reader.

Ethanol extract jam fruit leaves with a concentration of $100.40 \mu \mathrm{g} / \mathrm{mL}$ gave $82.70 \%$ of inhibition percentage while the percentage of captopril standard at a concentration of $5 \times 10^{-8} \mathrm{mg} / \mathrm{mL}$ was obtained as $34.42 \%$. The inhibition percentage of the ethanol extract of leaves of jam fruit at $100.40 \mathrm{mg} / \mathrm{mL}$ was not greater than the inhibition percentage of captopril, but it showed that the extract had activity as an ACE inhibitor. Extract of $M$. calabura leaves gave $\mathrm{IC}_{50}$ values of $1.25 \mu \mathrm{g} / \mathrm{mL}$ (Table 1 ).

Inhibitory activities of ACE by ethanol extract of leaves of jam fruit were included active depended on a category by Elbl and Wagner [11]. For the fractions, $\mathrm{IC}_{50}$ of ACE tests were done to fraction which had the active ACE inhibitory activity. Ethyl acetate gave the smallest value of $\mathrm{IC}_{5}$. Inhibition percentage at 8.33 ppm of the hexane, ethyl acetate, and
butanol fractions was 55.21;81.24;70.32, consecutively (Table 2).

\section{TPC assay}

Folin-Ciocalteu reagent is a redox reagent that will react with the polyphenol compounds. It is believed that the Folin-Ciocalteu reagent contains heteropoly molybdate phosphotungstate. The series of reversible reduction reaction of one or two electrons produces a blue compound which is PMoW110404- [12]. Tests performed at the maximum wavelength of $740 \mathrm{~nm}$. Another research on ethyl acetate fraction of jam fruit leaves obtained GAE values of $871.71 \pm 8.27 \mathrm{mg} / 100 \mathrm{~g}$ dry weight of crude extract [13]. The results were written in Table 3.
Table 1: Inhibition percentage of ACE by ethanol extract of jam fruit leaf

\begin{tabular}{llcl}
\hline $\begin{array}{l}\text { Concentration } \\
(\boldsymbol{\mu g} / \mathbf{m L})\end{array}$ & $\begin{array}{l}\text { Inhibition } \\
(\%)\end{array}$ & Regression equation & $\begin{array}{l}\mathrm{IC}_{50} \\
(\boldsymbol{\mu g} / \mathbf{m L})\end{array}$ \\
\hline 8.37 & $65.66 \pm 2.37$ & $\mathrm{Y}=\frac{100}{1+10^{\left(0.09583-\mathrm{x}^{*} 0.3038\right)}}$ & 1.25 \\
4.18 & $58.08 \pm 1.67$ & & \\
& & & \\
1.09 & $52.66 \pm 1.12$ & $\mathrm{R}^{2}=0.9755$ & \\
0.52 & $48.27 \pm 0.83$ & & \\
\hline
\end{tabular}

ACE: Angiotensin I-converting enzyme, $\mathrm{IC}_{50}$ : Inhibitory concentration $50 \%$

Table 2: Inhibition percentage of ACE by ethyl acetate fraction of jam fruit leaf

\begin{tabular}{llll}
\hline $\begin{array}{l}\text { Concentration } \\
(\boldsymbol{\mu g} / \mathbf{m L})\end{array}$ & Inhibition (\%) & $\begin{array}{l}\text { Regression } \\
\text { equation }\end{array}$ & $\begin{array}{l}\mathbf{I C}_{50} \\
(\boldsymbol{\mu g} / \mathbf{m L})\end{array}$ \\
\hline 8.33 & $81.24 \pm 0.13$ & $\begin{array}{l}\mathrm{Y}=4.0459 \mathrm{x}+47.469 \\
\mathrm{R}^{2}=0.9894\end{array}$ & 0.63 \\
4.17 & $63.32 \pm 0.14$ & & \\
2.08 & $57.80 \pm 1.13$ & & \\
1.04 & $52.20 \pm 0.56$ & & \\
0.52 & $48.11 \pm 0.86$ & & \\
\hline ACE: Angiotensin I-converting enzyme, IC : Inhibitory concentration $50 \%$
\end{tabular}

Table 3: TPC content of jam fruit fractions

\begin{tabular}{ll}
\hline Sample & TPC content (mg/g extract) \\
\hline Hexane fraction & $33.61 \pm 0.62$ \\
Ethyl acetate fraction & $74.90 \pm 1.32$ \\
Butanol fraction & $41.94 \pm 0.83$ \\
\hline
\end{tabular}

TPC: Total phenolic content

Table 4: Flavonoid content of jam fruit fractions

\begin{tabular}{ll}
\hline Sample & TF $(\mathbf{m g} / \mathbf{g}$ extract) \\
\hline Hexane fraction & $5.53 \pm 0.42$ \\
Ethyl acetate fraction & $10.91 \pm 0.50$ \\
Butanol fraction & $5.63 \pm 0.83$ \\
\hline
\end{tabular}

TF: Total flavonoid

\section{TF assay}

Measurement of TFs was performed according to the method of Chang et al. which used aluminum chloride reagent [7]. The principle of measurement of TFs is complex formation ketone group and a hydroxyl group $\mathrm{C}$ ring flavonoids or the hydroxyl group at the ortho position A or B ring flavonoids with aluminum chloride [5]. The complex will provide a bathochromic shift in the absorption of flavonoids that can be tested the levels of TFs. The test result showed the value of TF of jam fruit leaves extract was $47.79 \mathrm{mg} \mathrm{QE} / \mathrm{g}$ extract. The test was done as well to the fractions, and ethyl acetate gave the highest value of TF.

The study in Taiwan obtained results that water fraction of jam fruit leaf provided significant hypotensive effects compared with control [3]. Researches which were done previously showed that jam fruit leaves contain flavonoids, phenolic compounds, saponins with flavonoids, and steroids as most commonly found in the leaves of jam fruit. ACE inhibitory activity by flavonoids had been extensively tested and resulted that some of the flavonoids effectively inhibit the activity of ACE. Some flavonoids were found to provide ACE inhibitory activity present in jam fruit leaf extract is chalcone, quercetin, and genistein $[14,15]$. In jam fruit leaf, ethyl acetate which gave the highest value of inhibition activity has the highest value of phenolic content and TF. This may indicates that flavonoid and other phenolic compounds in jam fruit leaves gave ACE inhibitory activity to jam fruit leaves. Further 
research can be done to explore further information about active chemical constituents of jam fruit leaf as a hypotensive agent.

\section{CONCLUSION}

Ethyl acetate fraction of jam fruit leaf had the highest level of flavonoid, phenolic compound, and ACE inhibitory activity. IC $_{50}$ value of the most active fraction, ethyl acetate fraction was $0.63 \mu \mathrm{g} / \mathrm{mL}$. The flavonoid and phenolic content of ethyl acetate fraction of jam fruit leaf were $10.91 \mathrm{mg} / \mathrm{g}$ extract QE and $74.90 \mathrm{mg} / \mathrm{g}$ extract GAE.

\section{ACKNOWLEDGMENT}

This study was supported by the Directorate of Research and Community Services, University of Indonesia.

\section{REFERENCES}

1. Lim SS, Vos T, Flaxman AD, Danaei G, Shibuya K, Adair-Rohani H, et al. A comparative risk assessment of burden of disease and injury attributable to 67 risk factors and risk factor clusters in 21 regions, 1990-2010: A systematic analysis for the Global Burden of Disease Study 2010. Lancet 2012;380(9859):2224-60.

2. Indonesian Mnistry of Health. Basic Health Research 2013. Jakarta: Indonesian Ministry of Health; 2013.

3. Shih CD, Chen JJ, Lee HH. Activation of nitric oxide signaling pathway mediates hypotensive effect of Muntingia calabura L. (Tiliaceae) leaf extract. Am J Chin Med 2006;34:857-72.

4. Harrison C, Acharya KR. ACE for all - A molecular perspective. J Cell Commun Signal 2014;8(3):195-210.

5. Ferrari R, Boersma E. The impact of ACE inhibition on all-cause and cardiovascular mortality in contemporary hypertension trials: A review. Expert Rev Cardiovasc Ther 2013;11(6):705-17.

6. Al-Saeedi AH, Hossain MA. Evaluation of total phenols, total flavonoids and antioxidant activity of the leaves crude extracts of locally grown pigeon pea traditionally used in Sultanate of Oman for the treatment of jaundice and diabetes. J Coast Life Med 2015;3(4):317-21.

7. Chang C, Yang M, Wen H, Chern J. Estimation of total flavonoids content in propolis by two complementary colorimetric methods.
J Food Drug Anal 2002;10(3):178-82.

8. Lam le H, Shimamura T, Sakaguchi K, Noguchi K, Ishiyama M, Fujimura Y, et al. Assay of angiotensin I-converting enzyme-inhibiting activity based on the detection of 3-hydroxybutyric acid. Anal Biochem 2007;364(9):104-11.

9. Serra CP, Côrtes SF, Lombardi JA, Braga de Oliveira A, Braga FC. Validation of a colorimetric assay for the in vitro screening of inhibitors of angiotensin-converting enzyme (ACE) from plant extracts. Phytomedicine 2005;12(6-7):424-32.

10. Lam le H, Shimamura T, Manabe S, Ishiyama M, Ukeda H. Assay of angiotensin I-converting enzyme-inhibiting activity based on the detection of 3-hydroxybutyrate with water-soluble tetrazolium salt. Anal Sci 2008;24(8):1057-60.

11. Braga FC, Serra CP, Viana NS Jr, Oliveira AB, Côrtes SF, Lombardi JA. Angiotensin-converting enzyme inhibition by Brazilian plants. Fitoterapia 2007;78(5):353-8.

12. Huang D, Ou B, Prior RL. The chemistry behind antioxidant capacity assays. J Agric Food Chem 2005;53(6):1841-56.

13. Balan T, Sani MH, Mumtaz Ahmad SH, Suppaiah V, Mohtarrudin N, Zakaria ZA. Antioxidant and anti-inflammatory activities contribute to the prophylactic effect of semi-purified fractions obtained from the crude methanol extract of Muntingia calabura leaves against gastric ulceration in rats. J Ethnopharmacol 2015;164:1-15.

14. Balasuriya N, Rupasinghe HP. Antihypertensive properties of flavonoid-rich apple peel extract. Food Chem 2012;135(4):2320-5.

15. Cotin S, Calliste CA, Mazeron MC, Hantz S, Duroux JL, Rawlinson WD, et al. Eight flavonoids and their potential as inhibitors of human cytomegalovirus replication. Antiviral Res 2012;96(2):181-6.

16. Garcia-Mora P, Peñas E, Frias J, Zielinski H, Wiczkowski W, Zielinska D, et al. High-pressure-assisted enzymatic release of peptides and phenolics increases angiotensin converting enzyme I inhibitory and antioxidant activities of pinto bean hydrolysates. J Agric Food Chem 2016;64(8):1730-40

17. Huang WY, Davidge ST, Wu J. Bioactive natural constituents from food sources-potential use in hypertension prevention and treatment. Crit Rev Food Sci Nutr 2013;53(6):615-30.

18. Ottaviani JI, Actis-Goretta L, Villordo JJ, Fraga CG. Procyanidin structure defines the extent and specificity of angiotensin I converting enzyme inhibition. Biochimie 2006;88(3-4):359-65. 